\section{Cenzura wobec powojennej twórczości Leopolda Staffa. Przypadek Wikliny}

Kamila Budrowska

TEKSTY DRUGIE 2020, NR 6, S. 342-352

DOI: $10.18318 /$ td.2020.6.20 | ORCID: 0000-0003-3400-3966

1.

Stan badań nad twórczością autora Snów o potędze jest bardzo obszerny i stosowny do rangi artystycznej dzieła", nadal jednak istnieją tematy poruszane rzadko lub nieporuszane wcale. Mniej uwagi poświęcono stosunkowi

1 Wybrana bibliografia: J. Kwiatkowski U podstaw liryki Leopolda Staffa, PIW, Warszawa 1966; I. Maciejewska Leopold Staff. Lwowski okres twórczości, PIW, Warszawa 1965; I. Maciejewska Leopold Staff. Warszawski okres twórczości, PIW, Warszawa 1973; M. Wyka Leopold Staff, PIW, Warszawa 1985; Staff - poeta trzech pokoleń, opr. G. Leszczyński, seria: Przewodnik po lekturach, red. P. Kuncewicz, t. 29, Dom Wydawniczy „jota”, Warszawa 1990; W. Wójcik Staff i Różewicz. Studia historycznoliterackie, seria: Obrazy literatury XX wieku, red. M. Kisiel i W. Wójcik, t. 2, wyd. Kwartalnik Literacki FA-Art, Katowice 1999; M. Szczot Klasycyzm Leopolda Staffa, Wydawnictwo Poznańskie, Poznań 2004; Poezja Leopolda Staffa. Interpretacje, red. A. Czabanowska-Wróbel, P. Próchniak, M. Stala, Wydawnictwo U), Kraków 2005; D. Skwirut Klasycyzm w poezji Leopolda Staffa na tle dwudziestowiecznym. Historia recepcji i propozycje interpretacji, Collegium Columbinum, Kraków 2009; A. Czabanowska-Wróbel Złotnik i śpiewak. Poezja Leopolda Staffa i Bolesława Leśmiana w kręgu modernizmu, Universitas, Kraków 2009.
Projekt finansowany w ramach programu Ministra Nauki i Szkolnictwa Wyższego pod nazwą „Regionalna Inicjatywa Doskonałości" na lata 2019-2022, nr projektu oog/ RID/19, kwota finansowania 8791222 zł.

\section{Kamila}

Budrowska - prof. dr hab., pracownik Uniwersytetu w Białymstoku, kierownik Katedry Badań Filologicznych nad Cenzurą PRL i Edytorstwa.

Interesuje się związkami między literaturą a polityką, cenzurą oraz edytorstwem naukowym. Ostatnio opublikowała: „Biuletyn Informacyjno - Instrukcyjny" GUKPPiW. Wybór dokumentów z1955 r. [monograficzne wydanie źródeł] wybór, opracowanie naukowe i wstęp K. Budrowska, M. Budnik, W. Gardocki (2018). Kontakt: k.budrowska@uwb. edu.pl 
władz Polski Ludowej do poety i jego twórczości, jak dotąd nieopracowane pozostaje zagadnienie cenzurowania jego tekstów, nie przeanalizowano powojennych edycji dzieł, w tym tak istotnych, jak pięciotomowe Wiersze zebrane $^{2}$.W niniejszym szkicu zarysuję jedynie kilka kwestii oraz skomentuję znaleziska archiwalne: dalsza praca na pewno jest do podjęcia.

W 1945 roku Staff ma 67 lat i pisze o sobie, że ,jest w latach, w których się umiera". Nowy ład społeczno-polityczny zastaje zmęczonego wojną i schorowanego człowieka, który - chcąc odbudować podstawy egzystencji - próbuje, nie bez trudu, dostosować się do nowych zasad funkcjonowania kultury. Jego pozycję i sytuację buduje, z jednej strony, prestiż, jakim cieszy się w środowisku jako najstarszy żyjący poeta i mistrz skamandrytów (szczególnym uwielbieniem darzą go Tuwim i Różewicz), z drugiej - specyficzne traktowanie „starych mistrzów”, które można określić jako balansowanie pomiędzy honorowaniem a dyskredytacją. Gdy przyjrzeć się powojennym losom Leopolda Staffa i jego spuścizny, widać, że ze strony władz podlega gestom wyraźnym i intensywnie wykorzystywanym propagandowo. Ich zagęszczenie przypada na lata jubileuszu, zapaść następuje na przełomie lat 1951/1952 i trwa do później jesieni 1953.

W pierwszych powojennych miesiącach publikuje się wiersze poety w „Odrodzeniu”, ,Przekroju”, ,Dzienniku Literackim”. W numerze z 1 kwietnia 1945 roku "Odrodzenie" zamieszcza cykl wierszy pod zbiorczym tytułem Poezje (Martwa pogoda,Zniszczenie pomnika Chopina, Ukresu, Burzliwe niebo, Dwoistość, Przeczucie skowronka, Zatarty fresk) ${ }^{3}$. Dochodzi też do publikacji tomików poetyckich: najpierw Martwej pogody, pisanej jeszcze w czasie okupacji, potem kilku wyborów poezji w 1946, 1948 i 1949 oraz obszernych trzytomowych Poezji w opracowaniu Mieczysława Jastruna w 1950 roku4.

14 maja 1948 roku odbywa się uroczystość przyznania poecie nagrody PEN Clubu za działalność translatorską 22 stycznia 1949 Uniwersytet Jagielloński nadaje mu tytuł doktora honoris causa, a kilka dni później odbywa się

2 L. Staff Wiersze zebrane, t. 1-5, PIW, Warszawa 1955.

3 L. Staff Poezje, "Odrodzenie” 1945 nr 18, s. 1. Wszystkie wejdą potem do tomu Martwa pogoda; wiersz Burzliwe niebo pod zmienionym tytułem Skłócone niebo. L. Staff Martwa pogoda, Wyd. J. Mortkowicz, Warszawa-Kraków 1946.

4 A. Szałagan Leopold Staff, w: Współcześni polscy pisarze i badacze literatury. Słownik biobibliograficzny, red. J. Czachowska, A. Szałagan, WSiP, Warszawa, 2001, t. 7, s. 417-428.

5 Zob. J. Parandowski Mowa przy wręczaniu nagrody PEN Clubu, w: J. Parandowski Wspomnienia i sylwety, Ossolineum, Wrocław-Warszawa 1969, s. 14-15. 
w Warszawie uroczyste 70-lecie urodzin i 50-lecie pracy twórczej, uświetnione obecnością władz państwowych oraz władz Związku Literatów Polskich. Za organizacją jubileuszu stał niestrudzony uczeń i przyjaciel - Julian Tuwim $^{6}$, a reportaż z wydarzeń pojawił się nawet w Polskiej Kronice Filmowej. Staff otrzymuje z tej okazji od prezydenta Bieruta Krzyż Komandorski z Gwiazdą Odrodzenia Polski, poważną nagrodę pieniężną - dar od ZAIK-u oraz Związku Wydawców.

W roku jubileuszowym Związek Literatów Polskich ogłasza KsięgęPamiątkową ku czci Leopolda Staffa. 1878-1948, zredagowaną przez Juliana Tuwima i Juliusza Wiktora Gomulickiego7, a w 1951 roku honoruje się poetę Państwową Nagrodą Literacką I stopnia.

Tak oczywistym hołdom towarzyszy utajona dyskredytacja. Jak podaje Alicja Szałagan, po opuszczeniu popowstaniowej Warszawy i wojennej tułaczce autor Barwy miodu zatrzymuje się w Krakowie, w mieszkaniu siostry swej żony. Pozostaje w tym czasie bez środków do życia oraz bez możności prowadzenia - ze względu na ciasnotę w mieszkaniu - regularnej pracy literackiej. Emeryturę i przydział mieszkania zawdzięcza wieloletnim staraniom Tuwima, który opublikował w 1948 roku poruszające wspomnienie $O$ "moim" Staffie; tekst zwieńczony jest apelem do literatów i mieszkańców Warszawy o znalezienie pisarzowi jakiegoś lokum w stolicy ${ }^{8}$. Ze wspomnień Jana Parandowskiego wynika, że Staff otrzymał emeryturę dopiero w okolicach jubileuszu, odrzucił wcześniejsze propozycję pensji z „listy zasłużonych”.

W latach 1946 i 1947 autor Kowala pracuje nad antologiami poezji Młodej Polski i poezji międzywojennej, które wydać ma oficyna Trzaska, Evert i Michalski ${ }^{10}$. Trudna sytuacja nakładców prywatnych (oficynę zlikwidowano ostatecznie w $1951 \mathrm{roku}$ ) powoduje, że żadna z tych prac nie ukazuje się drukiem. Ogromny wysiłek redaktora idzie na marne i nie przynosi spodziewanej satysfakcji, a jedynie rozgoryczenie niesprawiedliwym osądem własnej pracy oraz sceptycyzmem wobec epok, uznanych przez władze za „burżuazyjne”.

6 T. Januszewski Wstęp, w: L. Staff, J. Tuwim Z tysiącem serdeczności. Korespondencja z lat 19111953, opr. T. Januszewski, I. Maciejewska, J. Stradecki, PIW, Warszawa 1974, S. 5-11.

7 Księga Pamiątkowa ku czci Leopolda Staffa. 1878-1948, red. J. Tuwim, J.W. Gomulicki, Związek Zawodowy Literatów Polskich, Warszawa 1949.

8 J. Tuwim O "moim"Staffie, w: L. Staff, J. Tuwim Z tysiącem serdeczności. Korespondencja z lat 19111953, S. 15-24.

9 J. Parandowski Leopold Staff, w: J. Parandowski Wspomnienia i sylwety, s. 18. 
Dotyka też Staffa sprawa dla każdego pisarza najboleśniejsza - przerwa w druku. Od początku roku 1952 do późnej jesieni 1953 nie udaje mu się ogłosić żadnego tomu: ani nowego, ani wznowienia, ani wyboru wierszy. Pomiędzy Wierszami wybranymi wydanymi przez Książkę i Wiedzę w połowie listopada 1951 roku $^{11}$ a drugim wydaniem Poezji w opracowaniu Mieczysława Jastruna, których druk ukończono 30 października 1953 roku ${ }^{12}$ następuje prawie dwuletnia przerwa. Wyjątkiem są w tym czasie nieliczne publikacje prasowe: kilka wierszy ogłoszono w 1952 roku w „Nowej Kulturze” i „Trybunie Wolności" oraz pojedyncze tłumaczenia. W sytuacji powojennego niedoboru książek, dużej aktywności pisarskiej artysty, wcześniejszej częstotliwości ogłaszania zbiorów luka taka świadczyć może o tym, że w okresie obowiązywania najsurowszej kontroli piśmiennictwa istniał - formalny bądź nieformalny - cenzuralny zakaz publikowania jego dzieł. Zapis na nazwisko ${ }^{13}$.

\section{2.}

Przy namyśle nad cenzurowaniem powojennego dorobku Staffa najważniejsze wydają się trzy zagadnienia. Po pierwsze, fakt, że w młodości poeta podlegał kontroli ze strony carskiej cenzury, mógł więc wypracować tekstowe sposoby „radzenia sobie” z opresją i uczynić z nich stały element poetyki ${ }^{14}$. Po drugie, wzmiankowana przerwa w druku przypadająca na najgłębszy stalinizm. Po trzecie, wydanie w 1954 roku, cenzurowanej w końcu roku 1953, absolutnie „nieprawomyślnej” Wikliny, pisanej tak, jak gdyby Polska Ludowa nigdy nie istniała.

W zespole archiwalnym GUKPPiW zachowało się sześć recenzji i recenzji wtórnych trzytomowych Poezji, tytułowanych początkowo jeszcze jako Wybór pism. Opinie, napisane w okresie od lipca do grudnia 1950, opracowano przed i po wydaniu dzieła, zezwalając na druk pierwotny oraz wskazując na możliwość dodruku lub wydania drugiego. Cenzorzy zdają sobie sprawę z pozycji

11 L. Staff Wiersze wybrane, KiW, Warszawa 1951 (wydanie trzecie).

12 L. Staff Poezje, wyb. M. Jastrun, PIW, Warszawa 1953, t. 1-3, (wydanie drugie).

13 Bezsporne potwierdzenie tego faktu wydaje się - przy obecnym stanie zachowania źródeł GUKPPiW - niemożliwe, bowiem księgi cenzorskich „zapisów” z lat 50. się nie zachowały. Być może podpowiedź przyniosą badania w archiwum pisarza.

14 Świat pod kontrolq. Wybór materiałów z archiwum cenzury rosyjskiej w Warszawie, opr. M. Prussak, Wydawnictwo "Krąg", Warszawa 1994, s. 123; K. Budrowska Literatura i pisarze wobec cenzury PRL. 1948-1958, Wydawnictwo Uniwersytetu w Białymstoku, Białystok 2009, s. 235-237. 
Staffa jako „klasyka” i uzasadniają potrzebę wydania jego poezji wyłącznie historycznie:

Dziś można by wiele dyskutować na temat podejścia Staffa do życia i poezji, poeta jest bowiem typowym przedstawicielem neoromantyzmu polskiego, którego hasła dawno już przebrzmiały. Dlatego też jego utwory należy traktować tak, jak się traktuje literaturę minionych epok, tj. historycznie ${ }^{15}$.

[...] Wiersze charakteryzują się brakiem tematyki społecznej - są w dużej większości refleksyjne, przeładowane filozoficzno-religijnymi rozważaniami, osobiste, liryczne lub opisowe. W doborze wierszy zbyt dużo miejsca poświęcono wierszom będącym rozmyślaniami na tematy religijne. Poza tym dobór utworów dokonany jest dobrze - daje pełny obraz twórczości międzywojennej Staffa. Wiersze na wysokim poziomie artystycznym - niekiedy trudno zrozumiałe dla surowego czytelnika przez przeładowanie filozoficzno-refleksyjną treścią [...]. Wydać w niskim nakładzie, wyeliminować pewną ilość wierszy o tematyce religijnej ${ }^{16}$.

Wiemy, że do druku doszło w grudniu 1950 roku i Poezje wydano w nakładzie ponad siedmiu tysięcy egzemplarzy. Nie udało się odnaleźć żadnych adnotacji o wprowadzeniu lub nie przekształceń, nie można zatem rozstrzygnąć, czy - niewymienione z nazw - wiersze religijne zostały usunięte. Z oględzin tomów wynika jednak, że zawierają pewną liczbę wierszy o takim charakterze. Przywoływane recenzje wskazują natomiast na najbardziej problematyczne, z punktu widzenia GUKPPiW, kwestie: brak tematyki społecznej, liczne odniesienia religijne, refleksje filozoficzne i osobiste. Aby wydać zgodę na druk - a pozytywna decyzja związana z edycją zapadła najpewniej wcześniej i na wyższym niż szeregowi cenzorzy szczeblu - sporządzający recenzje muszą te domniemane braki „usprawiedliwić” przyporządkowaniem twórczości Staffa do epok dawno minionych.

Warto także wrócić uwagę na przyjętą w Poezjach strategię edytorską: wybór mieści jedynie utwory powstałe w latach 1915-1944, co sugeruje czytelnikom w roku 1950 „historyczność” zbioru i pozwala uniknąć przypominania, że

\footnotetext{
15 AAN, GUKPPiW, 152, teczka 31/121, k. 427. Zasady przywoływania źródeł: modernizacji ortografii i interpunkcji towarzyszy zachowanie oryginalnej składni. 
Staff jest poetą żyjącym i twórczo aktywnym. Przyjętą przez redaktora zasadę można uznać za zewnątrztekstową formę ingerencji, uprzedzającą "właściwe" działania kontrolne.

W 1954 roku ogłoszono drukiem tomik Wiklina, mieszczący wiersze pisane w nowej rzeczywistości, a jednocześnie jakby poza nią. Publikacja została uznana za przełomową nie tylko ze względu na wyjątkową wartość artystyczną i nowatorstwo w obrębie twórczości poety, ale i na odporność na socrealistyczne postulaty. Późne wiersze Staffa przynoszą oryginalną refleksję wojenną i rewizję własnej twórczości.

Współczesna krytyka przyjęła zbiór bardzo dobrze, zachwycili się nim także badacze, wskazujący na pokrewieństwo z wyborami twórczymi Różewicza" ${ }^{17}$.

[...] Wikline - pisze Irena Maciejewska - chcąc ją możliwie poprawnie i w pełni odczytać, widzieć trzeba w tej podwójnej perspektywie. Po pierwsze w perspektywie trudnego rozrachunku poety z własną dotychczasową twórczością i po drugie, rozrachunku z ówczesną "produkcją” poetycką i jej charakterem.

Z dzisiejszej perspektywy widać, że Wiklina była pozycją ważną. Była pozycją nowatorską. Odciął się w niej Staff zarówno od uładzonej, „dworskiej” sielanki ówczesnej poezji, z jej postulatem jedynego, bardzo przy tym tradycjonalnego kanonu estetycznego, i odciął się od własnej przeszłości poetyckiej, przeszłości liczącej przeszło pół wieku i obejmującej dwie epoki poezji polskiej. Świadomie odwołał się do tej próby poezji, jaką zaproponował u nas po wojnie Tadeusz Różewicz ${ }^{\mathbf{1 8}}$.

\section{***:}

Wiklina liczy 59 utworów, z czego jedynie kilka ma „aktualną” tematykę (sześć wierszy „pokojowych" i cztery „wojenne”), a żadnego nie można uznać za tekst socrealistyczny ${ }^{19}$. Przypomnijmy, że tom trafił do GUKPPiW w październiku 1953 roku, gdzie przeszedł cenzorską kontrolę, a został wydrukowany - jak

17 Zob. na ten temat J. Kwiatkowski Leopold Staff, w: Literatura okresu Młodej Polski, red. K. Wyka, Warszawa 1968, t. 1, s. 484; W. Wójcik Wiklina zwiastująca wiosnę, w: W. Wójcik Staffi Różewicz, S. $52-65$.

I. Maciejewska Powojenny Staff, „Przegląd Humanistyczny” 1966 nr 3, s. 66.

Opozycyjność Wikliny wobec socrealizmu podkreślają W. Maciąg i I. Maciejewska, za: W. Wójcik. 
głosi stopka redakcyjna - 28 grudnia 1953 roku²0. Wiklinę można uznać zdecydowanie za utwór preodwilżowy: prekursorski, jeśli chodzi o wyrażony stosunek autora do obowiązującej konwencji artystycznej, a także widomy wyraz zmian w polityce kulturalnej państwa. Świadectwo łagodzenia „kursu”; ktoś musiał przecież jesienią 1953 roku wydać oficjalną zgodę na druk. Przy czym należy podkreślić, że Wiklina nie przynosi tekstów rozrachunkowych, a jedynie niesocrealistyczne, niezaangażowane, „cenzorsko obojętne”. Wydaje się, że ponownie została tu uruchomiona strategia pisania wobec rusofilskiego cenzora, która doskonale się Staffowi sprawdzała i w pierwszych latach wieku $\mathrm{XX}$, i w realiach PRL- $\mathrm{u}$.

W zespole archiwalnym GUKPPiW zachowały się trzy recenzje pierwotne Wikliny. Najobszerniejszą opinię przygotowuje cenzor Rutkowski. Tomik skierowano do oceny 29 października 1953 roku, a proponowany nakład to 5000 egzemplarzy.

Tom poezji L. Staffa pt. „Wiklina” obrazuje głęboki liryzm tego klasyka naszej poezji. Tematyka wierszy zawartych w tomie jest różna, przeważnie jednak są to wiersze liryczne, oddające urodę przyrody, lata, jesieni, piękna życia, pełnego zadumy nad losami ludzkości, jednostki, jej przeszłości i dalszych perspektyw. Wiersze tematycznie w bardzo małym stopniu związane są z tematyką dnia dzisiejszego w Polsce Ludowej i obozie socjalizmu. Są one raczej wynikiem różnych stanów duchowych poety i właściwej tylko jemu specyficznej kontemplacji nad człowiekiem i światem.

Poeta w wierszach tych kocha wszystko, co piękne: naturę, dobro, człowieka w jego znojnym, pracowitym trudzie i to oczywiście stanowi o artystycznym, a nawet ideowym wyrazie jego poezji: za mało jednak, a raczej niewspółmiernie mało, widzi poeta nasze życie, jego piękno i rozmach, jego trudności i jego walkę właśnie o piękno i dobro.

Spojrzenie [1 słowo nieczytelne - przyp. K.B.] jest zbyt humanistyczne, za mało w nim realizmu i odgłosów naszej epoki.

W wielu wierszach poeta staje się pięknoduchem, eliminującym ze swoich doznań jakiekolwiek treści społeczne.

Duża część utworów tchnie duchem na wskroś religijnym, kultu dla Chrystusa i jego rodziny [sic!]. Nie jest to oczywiście wada utworów, gdyż poeta $\mathrm{w}$ [1 słowo nieczytelne - przyp.K.B.] spraw boskich widzi ciężkie i niesprawiedliwie życie człowieka. 
Zastrzeżenia budzi jedynie układ wierszy, z tych względów proponuję wiersze z cz. III przenieść w całości jego [winno być: jako - przyp. K.B.] część I, ze względu na nieco bliższą nam tematykę. Ponadto do części I włączyć z tych samych względów następujące wiersze: „Dymy” z cz. II, „Serce" z cz. II, „Do ...” z cz. II, „Co pewien czas” z cz. II.

Układ pozostałych dwóch części dowolny.

Wniosek: Udzielić zezwolenia po dokonaniu ingerencji w układzie wierszy. Data 31.10. 1953 r. $^{21}$

29 października 1953 roku opinię sporządza cenzorka Bażańska (w recenzji wiele błędów ortograficznych).

Niestety nie sposób dokładnie określić, z jakiego okresu pochodzą wiersze zawarte w zbiorze „Wiklina”. Na podstawie tematyki utworów snuć można jedynie przypuszczenia, że pochodzą one z przedwojennego i okupacyjnego okresu (kilka ostatnich wierszy).

Wydawnictwo powinno przy każdym wierszu (szczególnie przy okupacyjnych) umieścić rok ich powstania [podkr. oryg. - K.B.].Trudno też powiedzieć, czym kierowało się wydawnictwo dzieląc wiersze na trzy cykle. Cykl pierwszy i drugi bowiem nie różni się pod względem tematyki i formy. Są to wiersze liryczne o zaskakujących finałach, odznaczające się bardzo wysokim poziomem artystycznym. Zaskakujące finały dają dyskretny humor, jakby pobłażliwy, ale pogodny uśmiech. Jeżeli chodzi o tematykę obu cykli, to nawiązuje ona do legend biblijnych i ludowych.

Zastanawia (lekcja niepewna - K. B.) mnie ostatni wiersz drugiego zbioru (sic!) zatytułowany „Chciałem już zamknąć dzień” (s. 54).Jego treść pozwala przypuszczać, że jest to utwór współczesny, zapowiadający cykl trzeci - wiersze współczesne. Rzeczywiście, w cyklu trzecim znajdujemy mocne akcenty pokojowe - cykl ten jednak kończą wiersze prawdopodobnie okupacyjne „Spokojne myśli...” (s. 63) i„Każdy dzień” (s. 64).Wniosek: Udzielić zezwolenia po uzupełnieniu datami powstania utworów ${ }^{22}$.

Pod spodem odręczna adnotacja zwierzchnika: „Zezwolenie na skład, 29. IX." (pomyłka, powinno być: $29 \mathrm{X}$ - K. B.), podpis nieczytelny.

21 AAN, GUKPPiW, 386, teczka 31/124, k. 1004-1005. 
Późniejszą o miesiąc recenzję przygotowuje cenzorka Renata Światycka. Opinia jest wynikiem standardowej procedury, kierującej książkę do druku już po udzieleniu zgody na skład i wprowadzeniu przez wydawcę ewentualnych zmian. Na dole odręczna adnotacja zwierzchnika: „Zezwolenie na druk, $28 \mathrm{XI}$ ".

Jest to zbiorek wierszy lirycznych. Przeważa tematyka refleksyjna. W rozważaniach autora nad sensem życia i bytu przeważa sceptycyzm - operuje on przeważnie paradoksem. Na końcu zamieszczono kilka wierszy o tematyce aktualnej (walka o pokój, odbudowa).

Wniosek: Udzielić zezwolenia ${ }^{23}$.

W opiniach zwraca się uwagę na liryzm Staffa, refleksyjność jego tekstów; po raz kolejny wykorzystuje się cenzorską metodę, czy modę wpisywania go w krąg „klasyków”, od których trudno wymagać zaangażowania w budowanie nowej rzeczywistości. Pojawia się nawet sugestia, że wiersze musiały powstać przed wojną i w czasie jej trwania. Konkretne uwagi dotyczą braku dat powstania pod utworami (to zarzut „typowy”, pojawiający się w recenzjach wielu tekstów poetyckich cenzurowanych w latach 50.) oraz układu całości. Pierwsza kwestia nie wydaje się kluczowa przy namyśle nad cenzurowaniem Wikliny, ponieważ dat takich nie wstawiono, druga - wymaga namysłu.

W tej postaci tekstowej, w jakiej weszła Wiklina do historycznoliterackiego obiegu, nie ma widocznego podziału na cykle. A przecież kilkakrotnie wzmiankują o nich cenzorzy kontrolujący utwór w październiku; dwie lub trzy części zbioru opisują jako „liryczno-refleksyjne” (cykle I i II) oraz „współczesny" (cykl III). Temat cyklizacji nie pojawia się natomiast w opinii Światyckiej, która czyta zbiór miesiąc później. Trudno przypuszczać, by pierwsi recenzenci mylili się w tak ważnej kwestii, a cenzor Światycka ją pominęła. Najwyraźniej istniejące wcześniej podziały wewnętrzne zostały pod wpływem postulatów GUKPPiW zlikwidowane! Podział na cykle liryczne pojawia się we wcześniejszej twórczości poety, choćby w tomach Łabędźi lira czy Sowim piórem, nie wydaje się zatem nieprawdopodobny ${ }^{24}$. Trudno wyrokować, kto mógł dokonać zmian: sam autor, czy PIW-owski redaktor za zgodą poety. Wiemy na pewno, że recenzje dzieli miesiąc: czas wystarczający by zmiany przeprowadzić i by mógł tego dokonać sam Staff.

AAN, GUKPPiW, 386, teczka 31/124, k. 1006 - 1007. 
Z porównania cenzorskich opinii i wersji drukowanej tomu wynika, że dokonano także przynajmniej jednej zmiany w kolejności utworów. Tę wersję tekstu, którą czyta cenzor Bażańska, kończą utwory Spokojne myśli i Każdy dzień, w wersji opublikowanej pojawia się jeszcze liryk Giordano Bruno, łagodzący „pesymistyczne” zakończenie całego zbioru. Utworu tego w tym miejscu w październiku 1953 roku jeszcze nie było, pojawia się na późniejszych etapach pracy nad całością. Ponownie trudno wyrokować, czy zmian dokonał autor, czy redakcja, wiemy jednak na pewno, że pierwotny układ zgłoszonych do kontroli wierszy był inny.

Można więc sformułować tezę, że - w związku z bezpośrednimi zaleceniami cenzuralnymi - w nowym tomie Staffa nie zachowano autorskiego układu wierszy i zaproponowanych przezeń cykli. GUKPPiW dał zgodę na druk takiej wersji Wikliny, którą uznać należy za niezgodną z pierwotną intencją autora. Przekształconą postać tekstu powtórzono potem w kolejnych wydaniach, w wydaniu drugim tomiku z 1955 roku i Wierszach zebranych. Stosunek władz do osoby i twórczości Leopolda Staffa jest charakterystyczny dla całokształtu powojennych przemian w kulturze. Meandry tych relacji odzwierciedlają proces zaostrzania i łagodzenia „kursu”, który zmienia się w okresie 1945-1957 (rok śmierci poety) kilkakrotnie. Skrajne punkty wyznacza tu jubileusz oraz prawie dwuletnia przerwa w druku. 


\section{Abstract}

\section{Kamila Budrowska}

UNIVERSITY OF BIAŁYSTOK

Censorship of Leopold Staff's Post-War Work: The Case of Wiklina [Osiers]

Budrowska describes the attitude of the authorities of the Polish People's Republic towards the poet Leopold Staff (1878-1957) in the period 1945-57. Discussing the censorship of his works she focuses on his 1954 poetry collection Wiklina [Osiers]. Most of the archival materials from the Main Office of Control of Press, Publications and Shows (GUKPPiW) that inform this article have not yet been examined by literary scholars. They indicate the following findings: first, in the years 1952-53 books by Staff were banned from publication; second, the printing of the collection Wiklina (1953) was a turning point in the poet's life and a harbinger of the thaw; and third, the censors interfered with the structure of the volume removing its cyclical structure and altering the order of the poems.

\section{Keywords}

Polish literature 1945-56, censorship, Polish People's Republic, Leopold Staff, Wiklina. 